\title{
Efforts to Improve The Learning Outcomes of Class IV Students in Natural Resources Materials Through Who's Quiz Card Media
}

\author{
Juriyah \\ SDN Ciputih 02 \\ enju.juriyah@gmail.com
}

\section{Article History}

accepted 01/11/2020

approved 08/11/2020

published $15 / 11 / 2020$

\begin{abstract}
This research was motivated by the low activity and student learning outcomes through the initial study of natural resources material in grade IV SD Negeri Ciputih 02 with less than optimal student learning outcomes. This study aims to analyze the impact of using the Who I quiz card media on the learning outcomes of students. The research was conducted in two cycles, each cycle consisting of two meetings and four stages, namely: planning, acting, observing, and reflecting. In the first cycle there were 4 students (30.8\%) and 9 students (69.2\%) who had completed, with a class average score of 71.53 . The results of cycle II reached 12 students (92.3\%) and 1 student (7.7\%) who had not completed, with a class average score of 80.76. Learning with the application of the right media produces good learning outcomes. It is proven that in each cycle there is a significant increase in learning outcomes. The conclusion is that the use of quiz card media who I am can improve student learning outcomes on natural resources material in class IV semester II SD Negeri Ciputih 02, Salem District, Brebes Regency.
\end{abstract}

Keywords: Natural Resources, Media Quiz Cards, Learning outcomes increase

\begin{abstract}
Abstrak
Penelitian ini dilatar belakangi oleh rendahnya aktivitas dan hasil belajar siswa melalui studi awal materi sumber daya alam di kelas IV SD Negeri Ciputih 02 dengan hasil belajar siswa kurang optimal. Penelitian ini bertujuan menganalisis dampak pemanfaatan media kartu kuis siapa aku terhadap hasil belajar peserta didik. Penelitian dilaksanakan dalam dua siklus, setiap siklus terdiri dari dua pertemuan dan empat tahapan yaitu : perencanaan, tindakan, pengamatan, dan refleksi. Pada siklus I yang belum tuntas 4 peserta didik $(30,8 \%)$ dan yang tuntas 9 peserta didik (69,2\%), dengan nilai rata-rata kelas 71,53. Hasil siklus II peserta didik yang tuntas mencapai $12(92,3 \%)$ dan yang belum tuntas 1 peserta didik $(7,7 \%)$, dengan nilai rata-rata kelas 80,76 . Pembelajaran dengan penerapan media yang tepat menghasilkan hasil belajar yang baik. Terbukti pada setiap siklus mengalami peningkatan hasil belajar yang signifikan. Kesimpulannya bahwa pemanfaatan media kartu kuis siapa aku dapat meningkatkan hasil belajar peserta didik pada materi sumber daya alam di kelas IV semester II SD Negeri Ciputih 02 Kecamatan Salem Kabupaten Brebes.
\end{abstract}

Kata kunci: Sumber Daya Alam, Media Kartu kuis, Hasil belajar meningkat

Social, Humanities, and Education Studies (SHEs): Conference Series https://jurnal.uns.ac.id/shes

p-ISSN 2620-9284

e-ISSN 2620-9292 


\section{PENDAHULUAN}

Berdasarkan hasil dari proses pembelajaran tentang materi sumber daya alam pada peserta didik kelas IV semester 2 SD Negeri Ciputih 02 yang dilaksanakan pada tanggal 1 Februari 2019 menunjukan bahwa hasil belajar sangat rendah. Tes hasil belajar sebelum menggunakan media kartu kuis siapa aku menunjukkan dari 13 Peserta didik hanya 5 peserta didik yang mampu mendapat hasil belajar diatas KKM yang ditetapkan 66. Sedangkan 8 peserta didik masih dibawah KKM ini artinya 38,50\% peserta didik yang mampu mencapai nilai diatas KKM sedangkan 61,50\% dibawah Ketuntasan Minimal (KKM). Dari permasalahan tersebut hendaknya dalam proses pembelajaran diperlukan media yang mampu mengatasi, memahami dan memecahkan konsep pembelajaran ilmu pengetahuan sosial pada materi sumber daya alam, sesuai dengan pendapat Hamalik (Albar, 2016) "media adalah, metode dan teknis yang digunakan dalam rangka lebih mengefektifkan komunikasi dan interaksi antara guru dan siswa dalam proses pendidikan dan pengajaran di sekolah." Media sangat bermanfaat dalam proses pembelajaran untuk memperlancar interaksi antara guru dan siswa, seperti yang diuraikan oleh Dayton yang dikutip oleh Depdiknas (Hayom Ahmadong, Amiruddin Kade, Srimulyani Sabang, 2017) mengidentifikasi beberapa manfaat media dalam pembelajaran yaitu: 1) penyampaian materi pelajaran dapat diseragamkan, 2) Proses pembelajaran menjadi lebih jelas dan menarik, 3) Proses pembelajaran menjadi lebih interaktif, 4) Efisiensi dalam waktu dan tenaga, 5) Meningkatkan kualitas hasil belajar siswa, 6) Media memungkinkan proses belajar dapat dilakukan dimana saja dan kapan saja, 7) Media dapat menumbuhkan sikap positif siswa terhadap materi dan proses belajar, 8) Mengubah peran guru kearah yang lebih positif dan produktif.

Kreatifitas guru menjadi salah satu faktor penting dalam keberhasilan pembelajaran, sesuai dengan teori yang diungkapkan Suprapto, E., dkk (Setiyati, 2017) "Guru dituntut untuk berpikir kreatif dalam mengatasi persoalan yang terjadi di kelas, termasuk menyampaikan materi pembelajaran agar tujuan dari kegiatan pembelajaran itu sendiri dapat tercapai secara maksimal." Guru yang kreatif dan inovatif akan memberikan landasan dan argumentasi pengambilan kebijakan sekolah berkaitan dengan peningkatan mutu sekolah melalui jalur pengembangan model pembelajaran di kelas. Sekolah yang para gurunya sudah mampu melakukan inovasi dengan meningkatkan kualitas pendidikan bagi para siswanya berpeluang besar untuk berkembang pesat, sebagaimana diungkapkan oleh Hargreaves (dalam Hopkins, 1993) "There is little school development without teacher development; and there is little teacher development without school development".

Menurut Sundayana (Nike Kristi Puspitasari, Asri Kusumaningratri, M.Pd, 2019) “ media adalah komponen sumber belajar atau wahana fisik yang mengandung materi instruksional di lingkungan siswa yang dapat merangsang siswa untuk belajar". Melalui media proses pembelajaran menjadi lebih jelas dan menarik perhatian siswa, media kartu kuis siapa aku merupakan pendekatan dalam pembelajaran yang dimulai dengan sajian atau tanya jawab lisan (ramah, terbuka, negosiasi) yang berkaitan dengan dunia nyata kehidupan peserta didik yang peoses pembelajaran dilakukan secara individu dan kemudian membentuk sebuah kelompok belajar. Dengan sajian/tanya jawab secara lisan tersebut akan melatih siswa untuk menumbuhkan sikap berani berpendapat. Hal ini sesuai yang dikutif dalam buku dari Direktorat Pembinaan Sekolah Dasar yang menyatakan bahwa "tes lisan bertujuan menumbuhkan sikap berani berpendapat, mengecek penguasaan pengetahuan untuk perbaikan pembelajaran, percaya diri dan kemampuan berkomunikasi secara efektif". Prinsip media kartu kuis siapa aku, menyajikan konsep pembelajaran yang mengaktifkan peserta didik, dimana peserta didik melakukan dan mengalami suatu konsep pembelajaran. Dengan media kartu kuis siapa aku seluruh peserta didik aktif dalam individu dan kelompok dan menemukan hasil pembelajaran dengan nyata. Oleh karena 
itu tepatlah jika media katu kuis siapa aku mampu mengatasi permasalahan dalam pembelajaran IImu Pengetahuan Sosial terutama pada materi sumber daya alam di kelas IV Sekolah Dasar Negeri Ciputih 02.

Oleh karena itu, untuk mengatasi permasalahan di atas peneliti melakukan penelitian dengan judul " Upaya Meningkatkan Hasil Belajar Peserta Didik Kelas IV Pada Materi Sumber Daya Alam Melalui Media Kartu Kuis Siapa Aku di Kelas IV SD Negeri Ciputih 02".

Rumusan masalah dalam penelitian ini adalah: (1) Bagaimana proses pembelajaran materi sumber daya alam dengan pemanfaatan media kartu kuis siapa aku pada peserta didik kelas IV semester II SD Negeri Ciputih 02?; (2) Bagaimana peningkatan aktivitas belajar peserta didik pada pembelajaran materi sumber daya alam dengan pemanfaatan media kartu kuis siapa aku pada peserta didik kelas IV semester II SD Negeri Ciputih 02?; dan (3) Apakah dengan pemanfaatan media kartu kuis siapa aku dapat meningkatkan hasil belajar peserta didik pada pembelajaran materi sumber daya alam pada peserta didik kelas IV semester II SD Negeri Ciputih $02 ?$

Tujuan penelitian adalah: (1) Mendeskripsi proses pembelajaran tentang materi sumber daya alam dengan menggunakan Media kartu kuis siapa aku. (2) Mendeskripsi peningkatan aktivitas peserta didik pembelajaran tentang materi sumber daya alam dengan menggunakan Media kartu kuis siapa aku dapat meningkatkan kinerja guru dalam proses pembelajaran. (3) Mendeskripsi peningkatan hasil peserta didik tentang materi sumber daya alam dengan menggunakan Media kartu kuis siapa aku.

\section{METODE}

Penelitian ini dilaksanakan dalam 2 (dua) siklus dan jenis penelitian ini adalah Penelitian Tindakan Kelas (PTK) yang, mengacu pada modifikasi diagram yang dikemukakan oleh Kemmis dan Mc Taggar dalam buku yang disusun Wiriaatmadja (Ardi Dj. Adjirante, Mestawaty As A, Muchlis Djirimu, 2017) tiap siklus dilakukan beberapa tahap, yaitu: 1) perencanaan tindakan, 2) pelaksanaan tindakan, 3) observasi, dan 4) refleksi.

Penelitian Tindakan Kelas (PTK) ini dilaksanakan di SD Negeri Ciputih 02 kelas IV pada semester II tahun pelajaran 2018/2019. Lama kegiatan sekitar 3 bulan yaitu mulai bulan Februari sampai dengan bulan April 2019.

Subjek penelitiannya adalah peserta didik kelas IV yang terdiri dari 4 peserta didik laki-laki dan 9 peserta didik perempuan.

Sumber data pada penelitian ini diperoleh dari data primer yang diperoleh peneliti secara langsung dari peserta didik, berupa nilai tes tertulis dan nilai kinerja dalam bentuk tugas kelompok, serta data sekunder yang diperoleh dari observasi peneliti dan kolaborator, berupa hasil diskusi dengan kolaborator yang dituangkan dalam tiap-tiap siklus.

Pengumpulan data pada penelitian ini menggunakan teknik penilaian tes tertulis dan non tes berupa penilaian unjuk kerja. Teknik penilaian tertulis dilakukan pada akhir pelajaran, sedangkan teknik penilaian non tes berupa penilaian unjuk kerja dilakukan melalui pengamatan terhadap aktivitas belajar peserta didik dan penilaian terhadap laporan hasil tugas. Observasi merupakan teknik evaluasi yang dilakukan dengan cara mengadakan pengamatan secara langsung terhadap obyek penelitian tentang kondisi lingkungan belajar dan aktivitas peserta didik.

Alat pengumpulan data yang digunakan adalah butir soal dalam bentuk uraian singkat yang disesuaikan dengan cakupan materi konsep sumber daya alam dan lembar observasi yang disusun berdasarkan variabel yang diamati.

Agar data yang diperoleh valid, maka dilakukan validasi. Validasi data untuk kuantitatif menggunakan instrumen butir soal dan validasi data untuk kualitatif 
menggunakan triangulasi sumber (kolaborasi dengan teman sejawat). Untuk memperoleh data yang valid, maka dibuatlah kisi-kisi instrumen yang di dalamnya mencakup keluasan materi dan indikator sebagai tolak ukur ketercapaian sesuai dengan penjabaran pada indikator kinerja. Data yang digunakan adalah hasil penilaian tes tertulis untuk mengukur hasil belajar, dan lembar observasi untuk mengukur aktivitas peserta didik dalam kegiatan pembelajaran. Data hasil observasi divalidasi melalui triagulasi, dalam hal ini peneliti hanya menggunakan triangulasi sumber dengan cara mencari data melalui kerja sama kolaborator.

Analisis data dilakukan dari hasil penilaian tes tertulis berupa ulangan harian, hasil pengamatan aktivitas peserta didik dan hasil tugas. Analisis data pada penelitian ini deskriptif komparatif yaitu membandingkan data kualitatif dari kondisi awal (prasiklus), siklus I dan siklus II. Seluruh hasil belajar peserta didik dianalisa oleh peneliti dan kolaborator sebagai indikator untuk mengetahui berhasil atau tidaknya tindakan ini dan digunakan sebagai acuan tindakan berikutnya.

\section{Deskripsi Kondisi Awal}

\section{HASIL DAN PEMBAHASAN}

Berdasarkan pengamatan dan kenyataan yang dialami oleh guru kelas IV ketika proses pembelajaran menunjukkan bahwa dalam kegiatan pembelajaran guru masih menerapkan pembelajaran konvensional yang kurang memberikan kesempatan peserta didik untuk aktif. Selain itu, guru juga dalam menyajikan bahan ajar tidak menggunakan media pembelajaran sehingga suasana pembelajaran kurang menarik dan kurang menyenangkan, peserta didik kurang aktif dalam pembelajaran, dan hasil belajarnya pun rendah. Hasil ulangan harian sebelum dilakukan penelitian adalah: (a) Jumlah peserta ulangan harian 13 peserta didik. (b) Jumlah peserta yang memperoleh nilai < 66 sebanyak 8 peserta didik. (c) Jumlah peserta yang memperoleh nilai $\geq 66$ sebanyak 5 peserta didik. (d) Nilai rata - rata kelas 58,46. Pada data tersebut, ketuntasan belajar yang dicapai sebesar: $5 / 13 \times 100 \%=38,50 \%$. Sedangkan peserta didik yang belum tuntas sebesar $8 / 13 \times 100 \%=61,50 \%$. Nilai tes rata-rata peserta didik sebesar 58,46. Ringkasan hasil belajar peserta didik sebelum menggunakan alat peraga kartu kuis siapa aku dapat dilihat pada tabel di bawah ini:

Tabel 4.1. Nilai Hasil Tes Awal

\begin{tabular}{clc} 
No & \multicolumn{1}{c}{ Hasil Tes } & Data Awal \\
1. & Nilai Tertinggi & 85 \\
2. & Nilai Terendah & 25 \\
3. & Rata-rata nilai tes & 58,46 \\
4. & Ketuntasan klasikal & $38,50 \%$ \\
\hline
\end{tabular}

Berikut ini tabel rentang nilai tes awal sebelum dilakukan penelitian.

Tabel 4.2 Rentang Nilai Tes Awal

\begin{tabular}{lccccc}
\hline No & Interval & $\begin{array}{c}\text { Frekuensi } \\
(\mathbf{N})\end{array}$ & $\begin{array}{c}\text { Nilai Tengah } \\
(\mathbf{Y})\end{array}$ & Presentase & $\begin{array}{c}\text { Jumlah } \\
(\text { NxY })\end{array}$ \\
\hline 1 & $21-25$ & 1 & 25 & $7,69 \%$ & 25 \\
2 & $26-30$ & - & - & - & - \\
3 & $31-35$ & - & - & - & - \\
4 & $36-40$ & - & - & - & - \\
5 & $41-45$ & 3 & 45 & $23,08 \%$ & 135 \\
6 & $46-50$ & 2 & 50 & $15,38 \%$ & 100 \\
7 & $51-55$ & 1 & 55 & $7,69 \%$ & 55 \\
8 & $56-60$ & 1 & 60 & $7,69 \%$ & 60 \\
9 & $61-65$ & - & - & - & - \\
10 & $66-70$ & 1 & 70 & $7,69 \%$ & 70 \\
\hline
\end{tabular}




\begin{tabular}{llllcc}
\hline 11 & $71-75$ & 2 & 75 & $15,38 \%$ & 150 \\
12 & $76-80$ & 1 & 80 & $7,69 \%$ & 80 \\
13 & $81-85$ & 1 & 85 & $7,69 \%$ & 85 \\
14 & $86-90$ & - & - & - & - \\
15 & $91-95$ & - & - & - & - \\
16 & $96-100$ & - & - & - & - \\
\hline \multicolumn{2}{r}{ Jumlah } & $\mathbf{1 3}$ & - & $\mathbf{1 0 0} \%$ & $\mathbf{7 6 0}$ \\
\hline
\end{tabular}

\section{Deskripsi Siklus I}

Berdasarkan hasil belajar peserta didik pada siklus I diperoleh data: (a) Jumlah peserta ulangan harian 13 peserta didik, (b) Jumlah peserta yang memperoleh nilai < 66 sebanyak 9 peserta didik. (c) Jumlah peserta yang memperoleh nilai $\geq 66$ sebanyak 4 peserta didik. (d) Nilai rata - rata kelas 71,53. Dari data tersebut, ketuntasan belajar peserta didik yang dicapai sebesar : $9 / 13 \times 100 \%=69,20 \%$. Sedangkan peserta didik yang belum tuntas sebesar $4 / 13 \times 100 \%=30,80 \%$. Nilai tes rata-rata peserta didik sebesar 71,53 . Ringkasan hasil belajar peserta didik pada siklus I dapat dilihat pada tabel di bawah ini:

Tabel 4.3 Nilai Hasil Belajar Tes Siklus I

\begin{tabular}{clc} 
No & \multicolumn{1}{c}{ Hasil Tes } & Data Awal \\
\hline 1. & Nilai Tertinggi & 90 \\
2. & Nilai Terendah & 40 \\
3. & Rata-rata nilai tes & 71,53 \\
4. & Ketuntasan klasikal & $69,20 \%$ \\
\hline
\end{tabular}

Berikut ini tabel rentang nilai tes siklus I setelah dilakukan penelitian.

Tabel 4.4 Rentang Nilai Hasil Belajar Siklus I

\begin{tabular}{lccccc} 
No & Interval & $\begin{array}{c}\text { Frekuensi } \\
(\mathrm{N})\end{array}$ & $\begin{array}{c}\text { Nilai Tengah } \\
(\mathrm{Y})\end{array}$ & Presentase & $\begin{array}{c}\text { Jumlah } \\
(\mathrm{NxY})\end{array}$ \\
\hline 1 & $36-40$ & 1 & 40 & $7,69 \%$ & 40 \\
2 & $41-45$ & - & - & - & - \\
3 & $46-50$ & - & - & - & - \\
4 & $51-55$ & - & - & - & - \\
5 & $56-60$ & 3 & 60 & $23,08 \%$ & 180 \\
6 & $61-65$ & - & - & - & - \\
7 & $66-70$ & 2 & 70 & $15,38 \%$ & 140 \\
8 & $71-75$ & 3 & 75 & $23,08 \%$ & 225 \\
9 & $76-80$ & 1 & 80 & $7,69 \%$ & 80 \\
10 & $81-85$ & 1 & 85 & $7,69 \%$ & 85 \\
11 & $86-90$ & 2 & - & $15,38 \%$ & 180 \\
12 & $91-95$ & - & - & - & - \\
13 & $96-100$ & - & - & $\mathbf{1 0 0} \%$ & $\mathbf{9 3 0}$ \\
\hline \multicolumn{7}{c}{ Jumlah } & $\mathbf{1 3}$ & - &
\end{tabular}

Dari tabel di atas menunjukkan bahwa hasil belajar dan aktivitas peserta didik mengalami peningkatan meskipun belum maksimal.

\section{Deskripsi Siklus II}

Berdasarkan hasil belajar peserta didik pada siklus II diperoleh data: (a) Jumlah peserta ulangan harian 13 peserta didik. (b) Jumlah peserta yang memperoleh nilai < 66 sebanyak 12 peserta didik. (c) Jumlah peserta yang memperoleh nilai $\geq 66$ sebanyak 1 peserta didik. (d) Nilai rata - rata kelas 80,76. Dari data tersebut, ketuntasan belajar peserta didik yang dicapai sebesar : $12 / 13 \times 100 \%=92,30 \%$. 
Sedangkan peserta didik yang belum tuntas sebesar $1 / 13 \times 100 \%=7,70 \%$. Nilai tes rata-rata peserta didik sebesar 80,76 . Hasil belajar peserta didik setelah menggunakan media kartu kuis siapa aku pada siklus II sebagai berikut:

Tabel 4.5 Nilai Hasil Belajar Siklus II

\begin{tabular}{clc}
\hline No & \multicolumn{1}{c}{ Hasil Tes } & Data Awal \\
\hline 1. & Nilai Tertinggi & 95 \\
2. & Nilai Terendah & 55 \\
3. & Rata-rata nilai tes & 80,76 \\
4. & Ketuntasan klasikal & $92,30 \%$ \\
\hline
\end{tabular}

Berikut ini tabel rentang nilai hasil belajar pada siklus II.

Tabel 4.6 Rentang Nilai Hasil Belajar Siklus II

\begin{tabular}{cccccc} 
No & Interval & $\begin{array}{c}\text { Frekuensi } \\
(\mathrm{N})\end{array}$ & $\begin{array}{c}\text { Nilai Tengah } \\
(\mathrm{Y})\end{array}$ & Presentase & $\begin{array}{c}\text { Jumlah } \\
(\mathrm{NxY})\end{array}$ \\
\hline 1 & $51-55$ & 1 & 55 & $7,69 \%$ & 55 \\
2 & $56-60$ & - & - & - & - \\
3 & $61-65$ & - & - & - & - \\
4 & $66-70$ & 3 & 70 & $23,08 \%$ & 210 \\
5 & $71-75$ & 2 & 75 & $15,38 \%$ & 150 \\
6 & $76-80$ & - & - & - & - \\
7 & $81-85$ & 2 & 95 & $15,38 \%$ & 170 \\
8 & $86-90$ & 2 & 90 & $15,38 \%$ & 180 \\
9 & $91-95$ & 3 & - & $23,08 \%$ & 285 \\
10 & $96-100$ & - & - & - & - \\
\hline & Jumlah & $\mathbf{1 3}$ & $\mathbf{1 0 0} \%$ & $\mathbf{1 . 0 5 0}$ \\
\hline
\end{tabular}

Berdasarkan tabel hasil belajar di atas menunjukkan bahwa setelah memanfaatkan media kartu kuis siapa aku secara maksimal oleh guru, aktivitas dan hasil belajar peserta didik meningkat.

\section{Pembahasan}

Data awal diperoleh dari nilai rata-rata hasil ulangan sebelum diadakan tindakan perbaikan pembelajaran sebesar 58,46 dengan ketuntasan klasikal 38,50\%. Setelah diadakan perbaikan dengan menggunakan alat peraga kartu kuis siapa aku materi sumber daya alam pada siklus I rata-rata nilai peserta didik mencapai 71,53 , sedangkan pada siklus II nilai rata-rata kelas mencapai 80,76. Pada siklus I ketuntasan belajar secara klasikal mencapai $69,20 \%$ dan pada siklus II ketuntasan belajar secara klasikal sebesar $92,30 \%$. Dengan demikian hasil belajar peserta didik pada siklus I belum memenuhi indikator yang telah ditetapkan dalam penelitian yaitu minimal $75 \%$ dari keseluruhan peserta didik mendapatkan nilai 66 atau mencapai ketuntasan $66 \%$. Sedangkan pada siklus II hasil belajar peserta didik sudah mencapai indikator yang telah ditetapkan dalam penelitian. Peningkatan tersebut sesuai dengan teori yang diungkapkan Sudjana (Bau, YS., Hasdin, dan Nurvita), 2017 bahwa media apabila dipahami secara garis besar, media adalah manusia, materi, atau kejadian yang membangun kondisi agar siswa mampu memperoleh pengetahuan, keterampilan, atau sikap.

Dari hasil penelitian diketahui bahwa nilai rata-rata dan ketuntasan kelas mengalami peningkatan yang cukup signifikan. Peningkatan nilai rata-rata peserta didik pada setiap siklusnya, karena peserta didik terlibat langsung secara aktif dalam proses pembelajaran, sehingga berdampak positif pada peningkatan hasil pembelajaran.

\section{SIMPULAN}


Berdasarkan hasil penelitian dan dan pembahasan yang telah diuraikan diperoleh kesimpulan yaitu: 1) Penggunaan media (alat peraga) kartu kuis siapa aku dapat diterapkan dalam pembelajaran secara efektif, karena dapat meningkatkan proses dan hasil belajar peserta didik. 2) Aktivitas peserta didik setelah pemanfaatan media kartu kuis siapa aku terhadap pembelajaran pada materi sumber daya alam mengalami peningkatan yang signifikan. Hal ini terbukti dari aktivitas positif peserta didik pada siklus I ke siklus II yang semula hanya 2,7 meningkat menjadi 3,15. Sehingga aktivitas belajar peserta didik meningkat sebesar 0,45. 3) Hasil belajar peserta didik setelah pemanfaatan media kartu kuis siapa aku pada materi sumber daya alam menunjukkan peningkatan yang signifikan. Peningkatan hasil belajar dari siklus I ke siklus II dari $69,20 \%$ menjadi $92,30 \%$, sehingga hasil belajar meningkat sebesar $20,10 \%$. Hal ini dapat ditunjukkan pula dari pencapaian rata-rata nilai peserta didik dari siklus I ke siklus II yang semula 71,53 menjadi 80,76, sehingga mengalami peningkatan sebesar 9,23 .

\section{DAFTAR PUSTAKA}

Albar. 2016. Jurnal Kreatif Tadulako Online Vol.4 No.2 ISSN 2354-614X. diunduh tanggal 16 November 2020

Ahmadong, H., Kade, A., Sabang, S. 2017. Jurnal Kreatif Tadulako Online. Vol.5 No.2 ISSN 2354-614X. diunduh tanggal 15 November 2020.

Adjirante, Ardi Dj., A Mestawaty, As., Djirimu, M. 2017. Jurnal Kreatif Tadulako Online. Vol.5 No.3 ISSN 2354-614X. diunduh tanggal 16 November 2020

Bau, Y.S., Hasdin, dan Nurvita. 2017. Jurnal Kreatif Tadulako Online. Vol.5 No.4 ISSN 2354-614X. diunduh tanggal 15 November 2020.

Direktorat Pembinaan Sekolah Dasar. Panduan Teknis Pembelajaran dan Penilaian di Sekolah Dasar. Jakarta Maret 2016.

Hargreaves (dalam Hopkins). 1993. Penelitian Tindakan Kelas. Jakarta : Universitas Terbuka.

Puspitasari, NK., Kusumaningratri, A., M.Pd. 2019. Jurnal Pendidikan dan Pembelajaran Anak Sekolah Dasar. Vol. 4 No. 02. diunduh tanggal 16 November 2020

Setiyati. 2017. Didaktikum: Jurnal Penelitian Tindakan Kelas. Vol.18 No.2 ISSN 20873557. diunduh tanggal 15 November 2020. 